\title{
The Optimal Level of Earnings Management Deterrence
}

\author{
Michael Ehud Yampuler ${ }^{1}$ \\ ${ }^{1}$ Department of Accounting and Taxation, C.T. Bauer College of Business, University of Houston (Main Campus), \\ Houston Texas, United States \\ Correspondence: Michael Ehud Yampuler, Department of Accounting and Taxation, C.T. Bauer College of Business, \\ University of Houston (Main Campus), Houston Texas, United States
}

Received: November 15, 2018

Accepted: December 11, 2018

Online Published: December 14, 2018

doi:10.5430/afr.v8n1p66

URL: https://doi.org/10.5430/afr.v8n1p66

\begin{abstract}
The social welfare costs of earnings management have been known to include the distortion of real investment decisions (resulting in inefficient allocation of resources), as well as deadweight loss incurred by the firms to manage earnings. One of the ways used to mitigate the effect of these costs is increasing the level of earnings management deterrence through legislation, regulation and enforcement, as in the Sarbanes-Oxley Act. However, by analyzing a rational expectations equilibrium that includes firms, investors, standard-setters, and legislators, I find that there are situations where such an increase in the level of earnings management deterrence may well be counter-productive. When considering the informational benefits of managing earnings and the substitution effect of accrual-based earnings management with real earnings management, increasing deterrence may result in decreasing the information value of financial reporting as well as increasing total social welfare costs of earnings management.
\end{abstract}

Keywords: accrual-based earnings management, real earnings management, Sarbanes-Oxley Act, information value of financial reporting

\section{Introduction}

The social welfare costs of earnings management have been known to include the distortion of real investment decisions (resulting in inefficient allocation of resources), as well as deadweight loss incurred by the firms to manage earnings. One of the ways used to mitigate the effect of these costs is increasing the level of earnings management deterrence through legislation, regulation and enforcement. The Sarbanes-Oxley Act, which was enacted in the United States following some major accounting debacles in the beginning of the millennium, aims right at this target, as its stated objective is "to protect investors by improving the accuracy and reliability of corporate disclosure made pursuant to the securities laws." The Act uses many tools to make earnings management less accessible for management: strengthening the external auditors, improving corporate governance (especially with audit committees), increasing SEC enforcement resources, increasing penalties for defrauding shareholders and even protecting "whistle-blowers". These measures have been shown to be effective in deterring accrual-based earnings management (Cohen, Dey, and Lys, 2008).

However, as the goal of enacting laws like the Sarbanes-Oxley Act is to benefit society, there are at least a couple of reasons why reducing accrual-based earnings management may not necessarily indicate an increase in social welfare. Several papers have argued that earnings management may be beneficial as it may enhance the information value of earnings. Managers may communicate private information to the public by exercising discretion over earnings (Arya, Glover, and Sunder, 2003). Another detrimental effect of deterring accrual-based earnings management is its substitution with real activities manipulation (Zang, 2012), often referred to as real earnings management. Real earnings management can be defined as myopic real business decisions like cutting vital R\&D costs, selling positive net present value assets, costly delaying of payments, over-producing inventory to defer fixed manufacturing costs, etc. Those decisions can indeed increase current performance, but they have a price in future performance that exceeds (in present value) the current benefit. Despite the total negative effect of those decisions, as real earnings management is in the realm of legitimate (though poor) business decision making, it is hard to deter with legislation. When combining all the benefits and costs of enacting laws like the Sarbanes-Oxley Act, legislators, standards-setters, and other market participants are faced with the problem of whether increasing accrual-based earnings management deterrence will have a positive effect on social welfare. 
In this paper I attempt to address the above problem by developing an analytical model that includes firms, investors, standard-setters, and legislators. Firms are assumed to have private information about their value, and when reporting this value can manage earnings (bearing potential costs for doing so, like risk of litigation, SEC enforcement etc.). Legislators decide on the level of earnings management deterrence, which determines the cost firms bear when deviating from the standards set by the standard-setters. Investors, being aware of the firms' incentives to manage earnings, try to deduce the firms' private information given the firms' report.

I find that in a rational expectations equilibrium, although there are situations where increasing the level of earning management deterrence increases social welfare, that is not always the case. When considering the informational benefits of managing earnings and the substitution effect of accrual-based earnings management with real earnings management, there are situations where a moderate level of earnings management deterrence is preferable to a higher one, and I discuss the conditions for when this phenomenon occurs.

\section{Literature Review}

A few studies have focused on the effect of increasing the stringency of regulation, standards, and oversight. Ewert and Wagenhofer (2005) discuss the economic effects of tightening accounting standards to restrict earnings management. In an analytical rational expectation model, they find that tightening standards increases earnings quality, however, this benefit may sometimes be outweighed by an increase in real earnings management, and an increase in the expected total cost of accrual-based earnings management. Drymiotes (2011) discusses the effect of increasing corporate governance oversight on earnings manipulation. In his model, manager's manipulative activities can also affect the effectiveness of monitoring. He finds that in some situations, increasing oversight may increase manipulation due to substituting one type of manipulation with another. Kang (2017) discusses the optimal stringency of accounting regulation. He finds that below a certain threshold of regulation stringency, increasing stringency can decrease accrual-based earnings management without inducing real earnings management.

Some papers have discussed the informational benefits of managing earnings. Arya, Glover, and Sunder (2003) show that even when earnings management conceals private information, information is conveyed by the level and pattern of managed earnings. Jayaraman (2008) finds that managed earnings convey information when compared to the cash flow. Jiraporn, Miller, Yoon, and Kim (2008) show in an empirical study that firms that manage earning more have, on average, less agency costs and higher firm value.

The costs of real earnings management, and the trade-off between accrual-based earnings management and real earnings management have been studied in a few papers. Vorst (2016) finds that real earnings management is associated with lower future operating performance, but the level of association depends on the various incentives to engage in real earnings management, as well as other factors that affect its associated costs and benefits. Moradi, Salehi, and Zamanirad (2015) discuss the choice managers have when maximizing their bonus between accrual-based earnings management and real earnings management. Chan, Chen, Chen, and Yu (2015) show how compensation clawback provisions, which are meant to deter managers from performing accrual-based earnings management by reducing their compensation retroactively, have an effect of increasing real earnings management. Zang (2012) documents empirical evidence consistent with managers substituting real earnings management and accrual-based earnings management. Cohen, Dey, and Lys (2008) found that the enacting of the Sarbanes-Oxley Act in 2002 had a reduction in accrual-based earnings management, but had the opposite effect on real earnings management.

In this paper I use previous findings regarding the informational value of managed earnings, and the substitution effect of accrual-based earnings management and real earnings management. However, I expand on the above papers by assuming that regulators and standard-setters are separate players, and the decision of one is not always adjusted to the decision of the other. I discuss a situation where standards do not adapt optimally to a change in regulation (which determines the level of earnings management deterrence), which affect the benefits derived from those regulations.

\section{The Basic Model}

Assume a specific item within the firms' financial statements has a characteristic $\mathrm{x}_{\mathrm{i}}$ (for firm i) which indicates its future economic value. For example, if a firm has an $R \& D$ expenditure for a drug and the $x_{i}$ of this item is the probability that the cost will produce future benefits (the drug will be approved.) Firms in the market have different values of $x_{i}$ and they are assumed to be distributed over the values [0,1] uniformly. I assume the $x_{i}$ is private information of the firm's management. 
An accounting standard s is also modeled with a value between 0 and 1, as in Dye (2002). This is a cutoff point of the event space into two possible alternatives for reporting the item (Note 1). If the item's value is $x_{i}>s$ then the accounting treatment for the item should be in the higher category, and if $\mathrm{xi}<\mathrm{s}$ then the item should be reported in the lower category. Regarding this modeling assumption, we can see that many existing accounting standards are really a partition into two cells ("asset" or "expense", "debt" or "equity", "consolidated" or "not consolidated" etc.). Thus, we can say that the modeling of the standard as a partition is intuitive.

I also assume (and construct the standards accordingly) that management (Note 2) prefer the users of the financial statements to think that their item is in the higher category (for instance, "asset" as the higher category and "expense" as the lower, "off balance sheet" as the higher category and "in balance sheet" as the lower etc.). The firm's management gains from going up a category because the investors predict a higher value of $\mathrm{x}$ to firms in the higher category. The gain to the firm from going up a category is assumed, for simplicity, to be a constant $g$ (Note 3 ).

The management can pay a (deadweight) $\operatorname{cost} \beta \cdot c\left(\mathrm{~s}-\mathrm{x}_{\mathrm{i}}\right)$ to increase the report of the item to be in the high category when the actual $x_{i}$ is smaller than $s$. The source of the cost for this intentional bias is the detrimental effect on the management due to increased risk of litigation, SEC enforcement, problems with auditors and loss of market confidence (and thus loss of management compensation). $\beta$ is a policy constant, determining the general level of earnings management deterrence enforced by the government in the market. The standard setter cannot change this constant. Regarding the c function, I assume c'>0, c" $>0$. I also assume that $c^{\prime}(0)$ is defined and greater than zero (Note 4).

I also do not restrict the earnings management cost for the management to be equal to the cost to the firm. The earnings management cost for the firm will be the detrimental effect of the above-mentioned events (litigation, SEC enforcement etc.) on the value of the firm. For simplicity, the cost to the firm is assumed to be $\beta \cdot \mathrm{k}_{\mathrm{c}} \cdot \mathrm{c}\left(\mathrm{s}-\mathrm{x}_{\mathrm{i}}\right)\left(w_{h} \mathrm{k}_{\mathrm{c}}\right.$ is a constant), which means it is a constant proportion of the cost to the management (Note 5).

The users of the financial statement are making a rational estimate of each firms' value of $\mathrm{x}$ using the information that they possess. I assume that users do not know the specific value of $\mathrm{x}$ for each firm, but they see the category reported in the financial statements (Note 6). However, they do know all the distributions and functions of the model.

Users, when making a best estimate for $\mathrm{x}_{\mathrm{i}}$, make errors. The errors are the differences between the expected value of $x_{i}$ given the reporting category of firm $i$ in equilibrium and the real value of $x_{i}$ (which is $x_{i}-E\left(x_{i} \mid\right.$ category)). The estimates of the users are calculated in a sophisticated way in equilibrium, considering the optimal earnings management decisions made by managements. I can define the value of information as a decreasing function of the average estimation error in the market. This value is decreasing because more estimation errors can create more distortion in real investment, credit and trade decisions making resource allocation in the market less efficient. I define the function $\mathrm{u}(1-\mathrm{AEE})$, when AEE is the average estimation error (under the assumptions of this model we can find that $0<\operatorname{AEE}<1$ ). The function $u$ is assumed to be weakly concave: $u^{\prime}>=0, u^{\prime \prime}<=0$ (Note 7).

To solve the standard setter problem, we need first to calculate which are the firms that will engage in earnings management and which will not. Given a standard $\mathrm{s}$, a decision of a firm with $\mathrm{x}_{\mathrm{i}}<\mathrm{s}$ will be to manage earnings if:

$$
\beta \cdot c\left(s-x_{i}\right)<g \Rightarrow s>x_{i}>s-c^{-1}\left(\frac{g}{\beta}\right) \quad \text { (where } \mathrm{c}^{-1} \text { is the reverse function of } \mathrm{c} \text { ) }
$$

We can define $s^{\prime}=s-c^{-1}\left(\frac{g}{\beta}\right)$ as the effective standard in equilibrium such that:

i)

ii)

$\mathrm{x}_{\mathrm{i}}>\mathrm{s}$ : management will report the high category without managing earnings (Note 8).

iii)

$\mathrm{s}^{\prime}<=\mathrm{x}_{\mathrm{i}}<=\mathrm{s}$ : management will choose to manage earnings and to report in the high category.

$\mathrm{x}_{\mathrm{i}}<\mathrm{s}^{\prime}$ : management will report in low category and find it optimal not to manage earnings.

We can see that the effective standard increases (which means less firms managing their earnings) with $\beta$, the level of earnings management deterrence. It also decreases (more firms managing earnings) with $\mathrm{g}$, the gain that the management has from reporting in the higher category relative to the low one (Note 9).

Assuming the standard setter is concerned with the social welfare, the standard setter problem is:

$$
\max _{s}\left[u\left(1-\left(\int_{0}^{s^{\prime}}\left|x_{i}-\frac{s^{\prime}}{2}\right| d x+\int_{s^{\prime}}^{1}\left|x_{i}-\frac{1+s^{\prime}}{2}\right| d x\right)\right)-\int_{s^{\prime}}^{s} \beta k_{c} c\left(s-x_{i}\right) d x\right] \quad(0 \leq s \leq 1)
$$

The expression inside the $\mathrm{u}$ function calculates the average estimation error of the users. Their estimation considers the effective standard in equilibrium s'.

It is easy to understand from the model that only minimizing earnings management cannot be the goal of the standard setter. For example, if the standard is set at $s=0$ or $s=1$ then no earnings management is necessary, however the value 
of information is at its lowest. This means that the standard setter should find the balance between those two components to minimize the friction in the information production process (an inner solution). However, corner solutions resulting in $s=0$ or $s=1$ are possible (Note 10$)$.

Assuming there is an inner solution, simplifying the standard setter's problem gives us:

$$
\left.\max _{s}\left[u\left(1-\left(\left(1+s^{\prime}\right)^{2}+s^{\prime 2}\right) / 4\right)-s^{\prime}\right)-\int_{s^{\prime}}^{s} \beta k_{c} c\left(s-x_{i}\right) d x\right]
$$

Since ( $s^{\prime}-s$ ) is a constant (given $g$ and $\beta$ ) for any $s$, then the right integral is also a constant for any $s$. Deriving the first order condition gives us: $\mathrm{u}^{\prime}(\cdot)^{*}\left(\mathrm{~s}^{\prime}-1 / 2\right)=0 \Rightarrow \mathrm{s}^{\prime}=1 / 2, \mathrm{~s}^{\prime}=1 / 2+\mathrm{c}^{-1}(\mathrm{~g} / \beta)$

This solution means that the effective standard is always $s^{\prime}=1 / 2$ for any $g$ and $\beta$ (Note 11 ), however the formal standard will be above $1 / 2$. We can see that if there were no earnings management costs, the optimal standard would have been $1 / 2$. Therefore, if standards are flexible, earnings management will not change the value of information in the market and will merely be a deadweight cost.

Now I keep on assuming standards are flexible, and that they are adjusted to their optimal level following any change in $\beta$, and I ask whether raising the level of earnings management deterrence $\beta$ results in an increase in social welfare. First, I define the first-best solution as a state in which there are no earnings management costs and the standard is the one that maximizes the value of information. I can prove the following proposition:

Proposition: Assuming flexible standards (adjusted to their optimal level given any level of government deterrence $\beta$ ), raising the level of deterrence $\beta$ to infinity will maximize social welfare (bring the market to its first best solution).

Proof: in appendix A.

Proposition 1 asserts that with the assumptions of my basic model, increasing the level of earnings management deterrence to infinity is an optimal policy for the government. Figure 1 shows an example of the effect of $\beta$ on the social welfare. The function and parameters used (and which satisfy all the above assumptions) are:

$u(x)=-1000\left(e^{(1-x)}-1\right)+200, c(x)=200\left(e^{x}-1\right), g=20, k_{c}=1$.

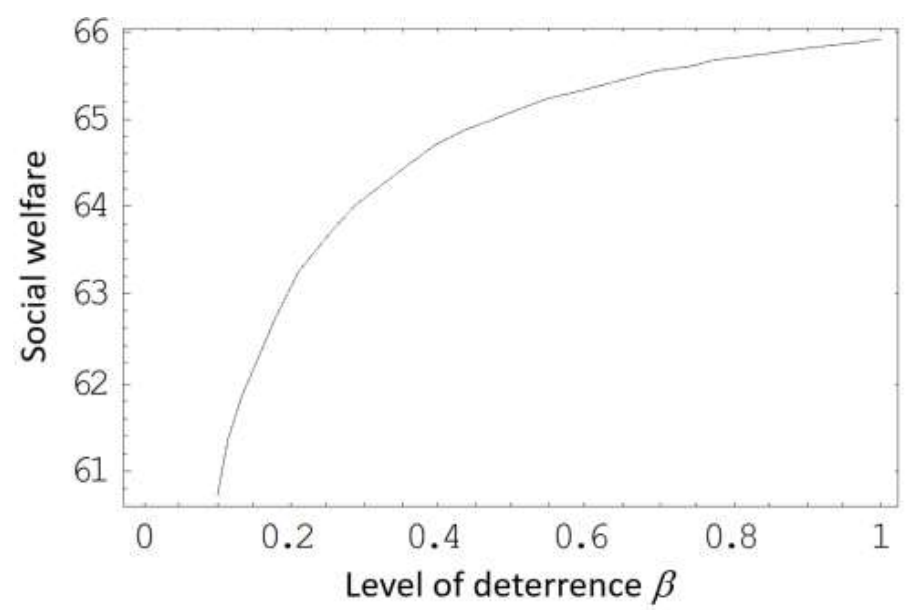

Figure 1. Social welfare as a function of earnings management deterrence $\beta$ when standards are flexible (adjustable to level of deterrence)

From Figure 1 we can also see that any decrease in the level of deterrence decreases social welfare. Such a decrease could come not only from the government but also, for example, because of a financial innovation. Assume the market invents a financial instrument that is principally a debt contract, but which has characteristics of both debt and equity and is reported as equity, and which helps the management to manage its earnings easier. I show in Appendix B an example where this kind of innovation, after a new equilibrium is reached, can decrease the welfare of all individual firms and users. 
However, those results are strongly depended on our assumptions. The proceeding sections will introduce new assumptions into the model to highlight situations where a policy of increasing the level of earnings management deterrence might not be optimal, and the market is best kept with only a moderate level of deterrence and some earnings management.

\section{Sub-Optimal Sticky Accounting Standards}

In the last section I assumed that standards are always set by the standard setter to be the optimal ones, as a function of the level of earnings management deterrence. However, this assumption is problematic for at least two reasons. First, the standards and the level of deterrence are usually set by different entities that might not be in complete cooperation. Second, the standard setter agenda capacity is limited, and it is difficult to assume that each time there is a change in the level of deterrence, a sweeping change will be made to all standards.

Therefore, I assume that standards are sticky, and do not change whenever there is a change in the level of deterrence. Specifically, assume that the current standard is $s>0.5$ (which according to the results in section 3 , is a general result in equilibrium), but the effective standard s' might not be the optimal one (which is 0.5 ). The cause for this situation could be that in a past period the standard s was optimized by the standard setter given the level of deterrence that was present then, but since that period the level of deterrence changed while the standard stayed rigid.

Now I raise the question whether in this situation it is still always beneficial (from a social welfare point of view) to increase the level of deterrence as much as possible, or is it better to stay with a finite, moderate level of deterrence that would allow some presence of earnings management.

We know that given the standard $s$, the effective standard $s^{\prime}=s-c^{-1}(g / \beta)$. The social welfare is (similar to the expression in (2)):

$$
\left.\mathrm{u}\left(1-\left(\left(1+s^{\prime}\right)^{2}+{s^{\prime}}^{2}\right) / 4\right)-s^{\prime}\right)-\int_{s^{\prime}}^{s} \beta k_{c} c\left(s-x_{i}\right) d x
$$

The first order derivative of the social welfare with respect to $\beta$ is:

$$
\left.\mathrm{u}^{\prime}\left(1-\left(\left(1+s^{\prime}\right)^{2}+{s^{\prime}}^{2}\right) / 4\right)-s^{\prime}\right) \cdot\left[\left(0.5-s^{\prime}\right) c^{-1}(g / \beta) \cdot g / \beta^{2}\right]-\int_{s^{\prime}}^{s} k_{c} c\left(s-x_{i}\right) d x+k_{c} c^{\prime-1}(g / \beta) \cdot g^{2} / \beta^{2}
$$

The left term is the derivative of the utility of the users with respect to $\beta$. We can see that it is positive when s' $<0.5$, and negative when $\mathrm{s}^{\prime}>0.5$. The reason for that is that $\mathrm{s}^{\prime}=0.5$ maximizes the value of information, and that $\mathrm{s}^{\prime}$ increasing in $\beta$. This means that when $\beta$ is low such that $\mathrm{s}^{\prime}<0.5$, increasing $\beta$ will increase the value of information ( $\mathrm{s}^{\prime}$ gets closer to 0.5 ). However, when $\beta$ is big enough such that $0.5<\mathrm{s}^{\prime}<\mathrm{s}$, an increase in $\beta$ will decrease the value of information.

The last two right terms are the derivative of the total cost of earnings management with respect to $\beta$. Although we do not know the exact sign of this derivative, we know from section 3 that the total earnings management cost function is bounded by a decreasing function that goes to zero as $\beta$ goes to infinity: $g \cdot k_{c} \cdot c^{-1}(g / \beta)$.

Summing both derivatives we might face a trade-off in the region where $\beta$ is big enough to make $0.5<\mathrm{s}$ ' $<\mathrm{s}$. In this region, increasing $\beta$ further will decrease the value of information, but on the other hand it might also decrease the total earnings management costs. If the decrease in value of information effect is dominant over the decrease in earnings management cost effect, then it is better to keep $\beta$ on a finite, moderate level.

Figure 2 shows a numerical example of a situation where the first effect is dominant over the second. The functions and parameter used are: $\mathrm{u}(\mathrm{x})=-1000\left(\mathrm{e}^{(1-\mathrm{x})}-1\right)+200, \mathrm{c}(\mathrm{x})=200\left(\mathrm{e}^{\mathrm{x}}-1\right), \mathrm{g}=20, \mathrm{k}_{\mathrm{c}}=1, \mathrm{~s}=0.7$ (the predetermined rigid standard). 


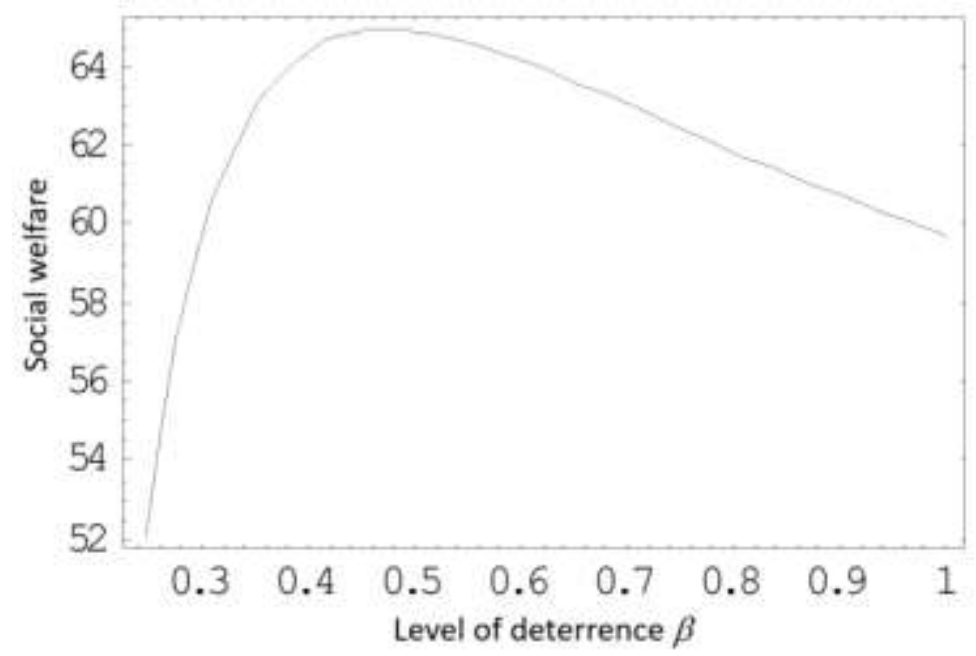

Figure 2. Social welfare as a function of earnings management deterrence $\beta$

when standards are sticky (not adjustable to level of deterrence)

When the standards are sticky there could be, in some situations, a positive role for some moderate level of earnings management. Using the management's ability to manage earnings can help produce better information for users by circumventing sub-optimal standards. This happens when the standards are too "strict", or in other words, when it is too difficult to qualify for the higher category. As an illustration, assume we had an R\&D standard for pharmaceutical companies that allowed only the top 5\% of the cases to qualify for capitalization (so only drugs that have a very high probability of succeeding will have their development cost capitalized). In some situations, it would be better to have a moderate level of deterrence such that, for example, the top $40 \%$ will report in the high category. In this case, the improvement in the value of information might be greater than the possible addition to the total cost of earnings management.

\section{Real Earnings Management}

In the previous sections I have assumed that earnings management involves a decision regarding only the way an item is reported in the financial statements. However, managers that are overly concerned about current performance can also choose to engage in various myopic real business decisions. Those decisions can indeed increase current performance, but they have a price in future performance that exceeds (in present value) the current benefit. Using again the pharmaceutical R\&D example from the previous section, such a myopic business decision could be to choose to develop a drug that has a lower expected return but is much less innovative, and so has more probability of approval. This decision lowers the economic value of the firm but makes enables the firm to show a higher $\mathrm{x}_{\mathrm{i}}$, potentially capitalizing more of the cost and sooner. Therefore, this myopic behavior, or real earnings management, has a deadweight loss of future earnings attached to it.

The two types of earnings management coexist as substitutes. The management can use them both at the same time, optimizing the mix between both such as to achieve the reporting goal. An important feature of the real earnings management is that it involves actions that are perceived as legitimate business decisions. Therefore, it is practically impossible to prevent those action by way of law or regulation, and difficult to fight them with litigation. This feature, in addition to the substitution effect with respect to non-real earnings management, can potentially change the way the level of deterrence affects the social welfare in the market, a change that is discussed in this section.

Assume we have a non-real earnings-management cost function as in the basic model (section 3), but now the management has an ability to engage in real earnings management. The management now has a choice regarding the optimal mix of earnings management types. Consider a firm with $\mathrm{x}_{\mathrm{i}}<\mathrm{s}$. The earnings management cost needed for reporting the high category are defined as: $\beta \cdot c\left(s-\mathrm{X}_{\mathrm{i}}-\mathrm{Z}\right)+\mathrm{r}(\mathrm{z})$

When $z$ is the amount of real earnings management, and $r(z)$ is the cost function of real earnings management (net deadweight loss of future earnings) for the management. I assume $r(z)$ is monotonically increasing and convex: $r$ ' $>0$, r' $>0$. 
In addition, with real earnings management I do not restrict the cost to the management to be the cost to the firm. The cost of real earnings management for the firm is assumed to be: $k_{r} r(z)$, when $k_{r}$ is a constant that is not necessarily equal $\mathrm{k}_{\mathrm{c}}$.

The optimal mix of earnings management types for a firm will be as follows:

$$
\min _{z}\left[\beta \cdot c\left(s-x_{i}-z\right)+r(z)\right]
$$

The first order condition will be:

$$
r^{\prime}(z)=\beta \cdot c^{\prime}\left(s-x_{i}-z\right) \Rightarrow \tilde{z}\left(x_{i}\right)
$$

When $\tilde{z}\left(x_{i}\right)$ is the optimal amount of real earnings management as a function of $x_{i}$. It is easy to show using implicit function differentiation that $\tilde{z}\left(x_{i}\right)$ decreases with $x_{i}$. and increases with $\beta$. After calculating the optimal mix, each firm's management decides whether it will manage earnings at all. A firm's management will manage earnings only if:

$$
\beta \cdot c\left(s-x_{i}-\tilde{z}\left(x_{i}\right)\right)+r\left(\tilde{z}\left(x_{i}\right)\right) \leq g
$$

Using the envelope theorem, we get that the derivative of the total optimal earnings management cost (for the management) with respect to $x_{i}$ is $-\beta \cdot c^{\prime}(\cdot)<0$. Therefore, the above inequality produces a cutoff $\tilde{x}(\beta)$ such that when $\tilde{x}(\beta)<\mathrm{x}_{\mathrm{i}}<\mathrm{s}$ then a firm manages earnings with an optimal mix, and when $\mathrm{x}_{\mathrm{i}}<\tilde{x}(\beta)$ then the firm does not manage earnings at all. The derivative of the cutoff $\tilde{x}(\beta)$ with respect to $\beta$ is:

$$
\frac{c(s-\tilde{x}(\beta)-\tilde{z}(\tilde{x}(\beta)))}{\beta} \cdot c^{\prime}(s-\tilde{x}(\beta)-\tilde{z}(\tilde{x}(\beta)))>0
$$

When considering the government's problem with regard to the optimal level of deterrence, we keep on assuming non-flexible standards and consequently the same definition of value of information as in the previous section, for the same reasons mentioned there. The share of firms reporting the category in which their real $x_{i}$ is in (Note 12) therefore is: $1-\mathrm{s}+\tilde{x}(\beta)$.

The problem of the government will be as follows:

$$
\max _{\beta}\left[u(1-s+\tilde{x}(\beta))-\int_{\tilde{x}(\beta)}^{s}\left[k_{r} r(\tilde{z}(x))+\beta k_{c} c(s-x-\tilde{z}(x))\right] d x\right]
$$

To use the envelope theorem, we can arrange the problem as follows:

$$
\operatorname{Max}_{\beta}\left[u(1-s-\tilde{x}(\beta))-\int_{\tilde{x}(\beta)}^{s}\left[\left(k_{r}-k_{c}\right) \cdot r(\tilde{z}(x))+k_{c} \cdot(r(\tilde{z}(x))+\beta \cdot c(s-x-\tilde{z}(x)))\right] d x\right]
$$

Using the fact that in equilibrium the firm with $\mathrm{x}_{\mathrm{i}}=\tilde{x}(\beta)$ will have total earnings management costs equal to $\mathrm{g}$, we get the first order condition as follows:

$$
\begin{gathered}
u^{\prime}(1-s-\tilde{x}(\beta)) \cdot \frac{\partial \tilde{x}(\beta)}{\partial \beta}-\int_{\tilde{x}(\beta)}^{s}\left[\left(k_{r}-k_{c}\right) \cdot r^{\prime}(\tilde{z}(x)) \cdot \partial \tilde{z}(x) / \partial \beta+k_{c} \cdot c(s-x-\tilde{z}(x))\right] d x-\left[\left(k_{r}-k_{c}\right) \cdot\right. \\
\left.r(\tilde{z}(x))+k_{c} g\right] \cdot \partial \tilde{x}(\beta) / \partial \beta=0
\end{gathered}
$$

We can see that for a large enough $\left(\mathrm{k}_{\mathrm{r}}-\mathrm{k}_{\mathrm{c}}\right)$ the above derivative becomes negative. This means that as the cost to the firm of raising the value of the item through real earnings management increases relative to the cost of doing that with non-real earnings management, increasing the level of earnings management deterrence will not help the market but even hurt it. In other words, this happens when managers find it easier to manage earnings through real earnings management, maybe because the personal implications are lighter, although it might be much costlier to the firm. In this situation we will want to have only a finite, moderate level of deterrence.

\section{Conclusion}

This paper provides analytical results regarding the optimal level of earnings management deterrence. I show that when standards are adjusted to maximize the social welfare whenever there is a change in the level of earnings management deterrence, it is optimal to apply infinite level of earnings management deterrence. However, when standards are sticky, and are not adjusted in an optimal way to the level of earnings management deterrence (or they were set optimally in the past, but they have not kept pace with the changes in the legal and regulatory environment) the above result does not always hold. A moderate level of deterrence allowing for some earnings management, although costly, might help mitigate the effect of the sub-optimal standards by improving their informative value. This added value of information can be greater than the added earnings management costs, and so social welfare maximizing. This phenomenon usually occurs when the level of earnings management deterrence is already high, 
and therefore, from a certain threshold, earnings management deterrence should not be increased, and sometimes even decreased.

When real earnings management was introduced to the model, I found that in cases where real earnings management is costly enough for the firm (relative to accrual-based earnings management), raising the level of deterrence, despite improving the informativeness of the report, would decrease social welfare due to the substitution between earnings management types. Therefore, in those cases, it would be social welfare maximizing to have only a moderate level of earnings management deterrence.

This paper can be of use to regulators and legislators when determining how stringent should compliance to accounting standards be, and how severely it should be enforced. The results show that in some cases higher deterrence may actually be counter-productive.

\section{Appendix A - Proof of proposition}

The standard that maximizes the value of information is calculated as follows:

$$
\begin{aligned}
& \max _{s}\left[u\left(1-\left(\int_{0}^{s}\left|x_{i}-\frac{s^{\prime}}{2}\right| d x+\int_{s^{\prime}}^{1}\left|x_{i}-\frac{1+s^{\prime}}{2}\right| d x\right)\right)\right] \\
& \left.\Rightarrow \max _{s}\left[u\left(1-\left(\left(1+s^{\prime}\right)^{2}+s^{\prime 2}\right) / 4\right)-s^{\prime}\right)\right]
\end{aligned}
$$

First order condition: $\mathrm{u}^{\prime}(\cdot) \cdot(\mathrm{s}-0.5)=0 \Rightarrow \mathrm{s}=0.5$

By the flexible standards assumptions we know that the equilibrium will be the solution to problem (A2), which is: $\mathrm{s}^{\prime}=0.5, \mathrm{~s}=0.5+\mathrm{c}^{-1}(\mathrm{~g} / \beta)$. The value of information is calculated using the effective standard $\mathrm{s}$, and so for every $\beta$ we have the first best standard (if we do not have a corner solution (Note 13)). Now it is left to show that when $\beta \rightarrow \infty$ total earnings management costs go to zero. The total earnings management costs are:

$$
\int_{s^{\prime}}^{s} \beta k_{c} c\left(s-x_{i}\right) d x=\int_{0.5}^{0.5+c^{-1}\left(\frac{g}{\beta}\right)} \beta k_{c} c\left(0.5+c^{-1}\left(\frac{g}{\beta}\right)-x_{i}\right) d x
$$

Because $\mathrm{c}$ is increasing, we know that the above integral is smaller than the following integral:

$$
<\int_{0.5}^{0.5+c^{-1}\left(\frac{g}{\beta}\right)} \beta k_{c} c\left(c^{-1}\left(\frac{g}{\beta}\right)\right) d x=\int_{0.5}^{0.5+c^{-1}\left(\frac{g}{\beta}\right)} g k_{c} d x=g k_{c} c^{-1}\left(\frac{g}{\beta}\right)
$$

And we can see that:

$$
\lim _{\beta \rightarrow \infty} g k_{c} c^{-1}\left(\frac{g}{\beta}\right)=0
$$

\section{Appendix B - A change in earnings management costs due to financial innovations}

In this appendix I discuss the possible effects of introducing the availability of financial innovations to my model. For example, assume the market invents a financial innovation in the form of a financial instrument that is principally a debt contract, but which has characteristics of both debt and equity and is reported as equity, helps the management to manage its earnings easier (Dye, Glover, and Sunder, 2015, discuss this kind of financial engineering activities).

Assume that this kind of innovation reduces $\beta$. I assume that the financial innovation is available for all firms to use (Note 14). Using the results of section 3, the effective standard s' stays the same (and consequently, so is the value of information for the users), but s must increase. This will make s "stricter", increasing it from $s_{1}$ to $s_{2}$. The number of firms engaging in earnings management will increase in equilibrium (which is measured by s-s'). Not all firms will be affected in the same way:

i) Firms in the regions $[0,0.5]$ and $\left[s_{2}, 1\right]$ will be indifferent to the change, because they did not manage earnings before or after the change, and the valuation of the users of their firm did not change either because s' stayed constant.

ii) Firms in the region $\left[s_{1}, s_{2}\right]$ will be hurt from the change, because now in order to be included in the high category they need to manage earnings, something they did not have to do before.

iii) For firms in the region $\left[0.5, s_{1}\right]$ there might be a mix of effects. Those firms managed earnings in both scenarios. The net effect depends on the shape of the function c.

The difference in effects for the firms might also explain their stand in issues regarding new standards. In this specific example, the change in standard setter's social welfare value is also undetermined.

An interesting sub-example is one in which we use a linear $\mathrm{c}$ function of the form: 


$$
\mathrm{c}(\mathrm{x})=\mathrm{n} \cdot \mathrm{x} \quad(\mathrm{n} \text { is a slope constant })
$$

In this specific example the group of firms in the region $\left[0.5, s_{1}\right]$, who were affected in an undetermined way in the more general example, are now clearly hurt from the change, as we can see in Figure B1:

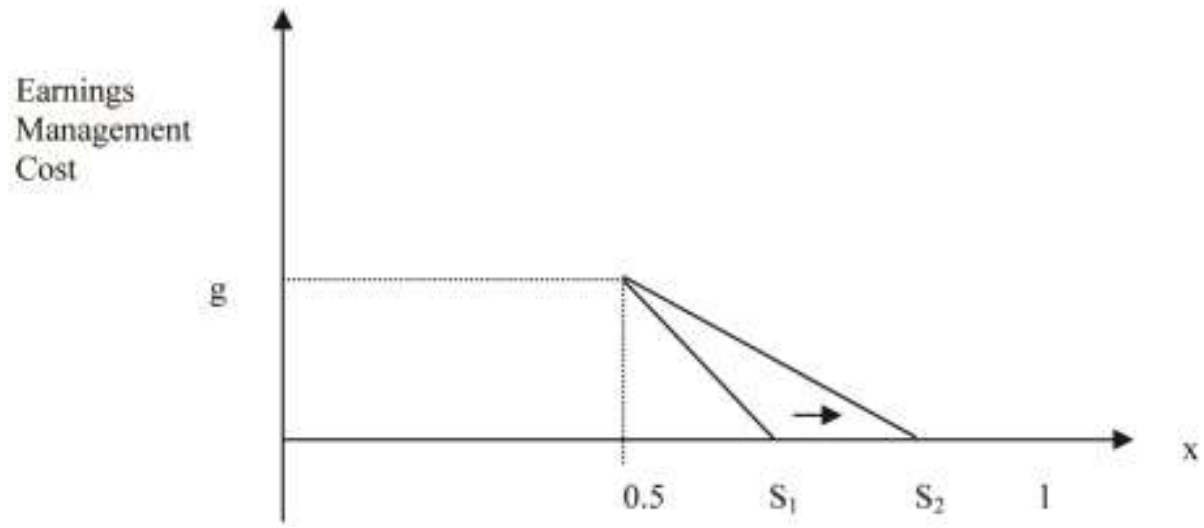

Figure B1. Earnings management cost change because of a financial innovation

In Figure B1 it is shown that the cost of earnings management for the marginal firm located s' $=0.5$ stayed the same before and after the change (because at $s^{\prime}=0.5$ we have the limit condition equating $\beta c(s-x)$ to $g$ which is a constant). The lower line is the old cost line, stretching up to $s_{1}$, and the upper line is the new cost line, stretching up to the new $\mathrm{s}_{2}$. We can also see clearly from this graph that the total cost of earnings management (in the graph - the area below the cost function) increased (and not only the number of firms managing earnings), and thus also the standard setter's objective function value decreased.

An interesting prediction of this simple example regards the ratcheting effect created by the introduction of a financial innovative derivative. After the innovation has become widely available, in equilibrium, its introduction will either hurt or at best keep costs at the same level as before for all the participants in the market (including all firms) and decrease the total social welfare objective function value of the standard setter. Following the innovation, the (nominal) standard is ratcheted upwards, throwing the market into a worse equilibrium. The model does not deal with the dynamics of the transformation, but trying to best guess the process, the firms who are first to adopt the financial innovations have an advantage over the others using tools which the users still do not discount for. At the end of the process, the late-moving firms are "forced" to apply the innovations because they are discounted anyhow for the potential use of them, so it is better to use them than to use more expensive tools.

An additional possible adverse effect of lowering the earnings management cost per dollar managed (like in a financial innovation) is the following. Assume that currently there is a two-category standard. If the change is significant enough, this might make the inner solution sub-optimal, and the standard setter would be better off setting the standard with only one treatment allowed, thus rendering the standard practically uninformative.

\section{References}

Arya, A., Glover, J., Sunder, S. (2003). Are unmanaged earnings always better for shareholders? Accounting Horizons, 17, 111-116. https://doi.org/10.2139/ssrn.322260

Bergstresser, D., \& Philippon, T. (2006). CEO Incentives and Earnings Management. Journal of Financial Economics, 80(3), 511-529. https://doi.org/10.1016/j.jfineco.2004.10.011

Chan, L. H., Chen, K. C. W., Chen, T. Y., \& Yu, Y. (2015). Substitution between Real and Accruals-Based Earnings Management after Voluntary Adoption of Compensation Clawback Provisions. The Accounting Review, 90(1), 147-174. https://doi.org/10.2308/accr-50862

Cohen, D. A., Dey, A., \& Lys, T. Z. (2008). Real and Accrual-Based Earnings Management in the Pre-and Post-Sarbane-Oxley Periods. The Accounting Review, 83(3), https://doi.org/10.2308/accr.2008.83.3.757

Drymiotes, G. C. (2011). Information Precision and Manipulation Incentives. Journal of Management Accounting Research, 23(1), 231-258. https://doi.org/10.2308/jmar-10067 
Dye, R. A. (1995). Strategic Accounting Choice and the Effects of Alternative Financial Reporting Requirements. Journal of Accounting Research, 23(2), 544 -574. https://doi.org/10.2307/2490826

Dye, R. A., \& Verrecchia, R.E. (1995). Discretion vs. Uniformity: Choices Among GAAP. The Accounting Review, 70(3), 389 - 415. http://www.jstor.org/stable/248531

Dye, R. A. (2002). Classification Manipulation and Nash Accounting Standards. Journal of Accounting Research, 40(4), 1125-1162. https://doi.org/10.1111/1475-679X.00084

Dye, R. A., Glover, J. C., Sunder, S. (2015). Financial Engineering and the Arms Race Between Accounting Standard Setters and Preparers. Accounting Horizons, 29(2), 265-295. https://doi.org/10.2308/acch-50992

Ewert, R., \& Wagenhofer, A. (2005). Economic Effects of Tightening Accounting Standards to Restrict Earnings Management. The Accounting Review, 80(4), 1101-1124. https://doi.org/10.2308/accr.2005.80.4.1101

Fields, T., Lys, T., \& Vincent, L. (2001). Empirical Research on Accounting Choice. Journal of Accounting and Economics, 31(1-3), 255-307. https://doi.org/10.1016/S0165-4101(01)00028-3

Healy, P. M. (1985). The Effect of Bonus Schemes on Accounting Decisions. Journal of Accounting and Economics, 7(1-3), 85-107. https://doi.org/10.1016/0165-4101(85)90029-1

Healy, P. M., \& Wahlen, J. M. (1999). A Review of the Earnings Management Literature and Its Implications for Standard Setting. Accounting Horizons, 13(4), 365-383. https://doi.org/10.2308/acch.1999.13.4.365

Jayaraman, S. (2008). Earnings Volatility, Cash Flow Volatility, and Informed Trading. Journal of Accounting Research, 46(4), 809-851. https://doi.org/10.1111/j.1475-679X.2008.00293.x

Jiraporn, P., Miller G. A., Yoon, S. S., Kim, Y. S. (2008). Is earnings management opportunistic or beneficial? An agency theory perspective. International review of Financial Analysis, 17(3), 622-634. https://doi.org/10.1016/j.irfa.2006.10.005

Kang, S. (2017). The optimal stringency of accounting regulation to alleviate time inconsistency problems. International Review of Economics \& $\quad$ Finance, 49, 190-210. https://doi.org/10.1016/j.iref.2016.10.012

Moradi, M., Salehi, M., \& Zamanirad, M. (2015). Analysis of incentive effects of managers' bonuses on real activities manipulation relevant to future operating performance. Management Decision, 53(2), 432-450. https://doi.org/10.1108/MD-04-2014-0172

Vorst, P. (2016). Real Earnings Management and Long-Term Operating Performance: The Role of Reversals in Discretionary Investment Cuts. The Accounting Review, 91(4), 1219-1256. https://doi.org/10.2308/accr-51281

Zang, A. Y. (2012). Evidence on the Trade-Off between Real Activities Manipulation and Accrual-Based Earnings Management. The Accounting Review, 87(2), 675-703. https://doi.org/10.2308/accr-10196

\section{Notes}

Note 1. It can be that different firms, users and auditors might have a somehow different notion of the exact cutoff point between the categories, however it is reasonable to assume that there is a commonly known average cutoff point.

Note 2. It may be that the conclusions of this paper also apply to contexts where agency problems exist. However, a nonagency context was chosen to simplify the exposition and analysis.

Note 3. This g could also be the optimal gain in a more general equilibrium in which the management decides on its optimal strategy regarding all the items in the financial statements, where it is possible that earnings management on one item can substitute for earnings management on another.

Note 4. I will use this regularity assumption in the proofs.

Note 5. The conversion from cost-to-management to cost-to-firm could take a more complex form. However, this simple form suffices for the intuition needed.

Note 6. I abstract in this model from the size of the item. I can, for example, assume that we are dividing the items into $\$ 1$ events. In any case, adding item size to the model, which will be independent of the value of e, will not add any interesting results. 
Note 7. The model in this paper takes the function $u$ as exogenous and decreasing in the extent of estimation errors. However, we can see this cost function as arising from an endogenous users' problem. Dye and Verrecchia (1995), for example, use an investment problem in which new investors are trying to estimate economic earnings of a firm in which the current shareholders try to maximize the current price choosing between reporting strategies. The worse the estimate will be so will be the investment decision.

Note 8. One can argue that if $x_{i}$ is an indication of an uncertain future value (like the success of an $R \& D$ project) then even firms with $\mathrm{x}_{\mathrm{i}}>\mathrm{s}$ can get a low realization in future periods. If I assume that the real $\mathrm{x}_{\mathrm{i}}$ is not revealed in future periods, a low realization can result in litigation against that firm, which means that it has costs of a similar type to those of firms that engage in earnings management. Using this assumption, we can see that raising the level of deterrence might even increase the effective standard s' to be greater than s, and when $\beta$ goes to infinity, s' will get closer to 1 , rendering the report uninformative. It is easy to see that with this assumption it is not optimal to increase $\beta$ to infinity. However, in the proceeding sections we would want to focus on other reasons for why $\beta$ should not go to infinity, and so to separate and emphasize the results of the proceeding sections I assumed that firms with $\mathrm{x}_{\mathrm{i}}>\mathrm{s}$ can report the high category without bearing any cost.

Note 9. The gain of the management is mostly attributed to the compensation structure. Healy (1985) brought evidence of an association between management bonus structure and earnings management. Bergstresser and Philippon (2006) provides evidence that earnings management, or the use of discretionary accruals to manipulate reported corporate earnings, is more pronounced at firms where the CEO's potential total compensation is more closely tied to the value of stock and option holdings. In this paper, to emphasize our results, I simplify and assume a constant gain from going up a category.

Note 10. In these situations, the users get no (value of information at a minimum) but also no earnings management costs. However, when we compare the welfare in these corner solutions to the social welfare in the best inner solution, which are the cost of earnings management for the firms plus a (higher) level of information, we get that the corner solution is preferable. If we denote the best inner solution as $\mathrm{s}_{1}$ (and the resulting $\mathrm{s}_{1}{ }^{\prime}$ ), we will get an inner solution if:

$$
\mathrm{u}\left(1-\left(\int_{0}^{s^{\prime}}\left|x_{i}-\frac{s^{\prime}}{2}\right| d x+\int_{s^{\prime}}^{1}\left|x_{i}-\frac{1+s^{\prime}}{2}\right| d x\right)\right)-\int_{s_{i^{\prime}}}^{s_{i}} \beta k_{c} c\left(s_{i}-x_{i}\right) d x-u\left(\int_{0}^{1}\left|x_{i}-\frac{1}{2}\right| d x\right)>0
$$

When the first two terms on the left-hand side are the social welfare in the inner solution and the third term is the social welfare in the corner solution. The interpretation of corner solutions is that the cost of earnings management in the best two-category standard is so high relative to the benefit it gives the users in their decision making, that it is better to make a standard with only one accounting treatment prescribed for all cases, and thus avoiding earnings management altogether. An example for a one-cell standard is the U.S. R\&D standard which provides only one accounting treatment (expensing) for all R\&D outlays, or FAS\#141 which leaves the purchase method as the only choice for consolidation.

Note 11. The value of the optimal standard is a result of the uniform distribution of $\mathrm{x}$ assumption. Changing the distribution of $\mathrm{x}$ will not change the intuition behind the main results in this paper.

Note 12. There are two ways to define the real $x_{i}$. One sees the real $x_{i}$ as the value after the real earnings management, because this is the actual real value of the item at this period. Another definition could be the original $\mathrm{x}_{\mathrm{i}}$ before all types of earnings management, because this enables the users to predict better the long run profitability. However, both definitions give the same value of information under the definition of value of information used in this section because a firm with an original $\mathrm{x}_{\mathrm{i}}<\mathrm{s}$ (before all types of earnings management) will not use real earnings management of more than $\mathrm{s}-\mathrm{x}_{\mathrm{i}}$, and so value after the real earnings management will also be below $\mathrm{s}$.

Note 13. I showed that a corner solution arises when the total earnings management costs are greater than the value of the information in the best inner solution. When $\beta$ goes to infinity I show that the total earnings management costs go to zero, and so the likelihood of a corner solution also goes to zero.

Note 14. The first firm that used the financial innovation had a first mover advantage, and it was optimal for that firm to use that tool. I am analyzing the situation after the innovation has become available for use to all firms. 